\title{
PEMBERDAYAAN PENGOLAH IKAN SKALA RUMAH TANGGA DI PROVINSI JAWA BARAT
}

\section{The Empowerment of Small Scale Fish Processors in West Java Province}

\author{
'Yaya Hudaya', Aida Vitayala S. Hubeis'2, Basita G. Sugihen² dan Anna Fatchiya² \\ ${ }^{1}$ Direktorat Jenderal Perikanan Tangkap, Kementerian Kelautan dan Perikanan, Indonesia \\ Jalan Medan Medeka Timur No.16, Jakarta Pusat, Telp/Faks: (62-21) 3453008 \\ ${ }^{2}$ Fakultas Ekologi Manusia, Institut Pertanian Bogor, Indonesia \\ Diterima tanggal: 29 April 2017 Diterima setelah perbaikan: 19 Juli 2017 \\ Disetujui terbit: 7 Desember 2017 \\ *email: red3mbe@gmail.com
}

\begin{abstract}
ABSTRAK
Pemberdayaan pengolah ikan di Provinsi Jawa Barat dilakukan dengan tujuan untuk meningkatkan kesejahteraan pelaku usaha, menjamin keamanan pangan produk yang dihasilkan, dan ikut menjaga kelestarian sumber daya ikan yang ada. Tujuan penelitian ini adalah untuk menganalisis kinerja pemberdayaan pengolah ikan skala rumah tangga dan dampaknya di Provinsi Jawa Barat. Metode analisis menggunakan uji beda Man Whitney $U$. Hipotesis penelitian ini adalah ada perbedaan nyata proses pemberdayaan pengolah ikan dan dampaknya di pesisir utara Kabupaten Cirebon dan selatan Kabupaten Sukabumi, Provinsi Jawa Barat. Hasil penelitian menunjukkan tidak ada perbedaan nyata proses pemberdayaan pengolah ikan dan dampaknya baik di pesisir utara Kabupaten Cirebon maupun di pesisir selatan Kabupaten Sukabumi. Kebijakan pemberdayaan pengolahan ikan skala rumah tangga di Provinsi Jawa Barat baik di pesisir utara maupun selatan tidak perlu dibedakan. Namun, intensitas pemberdayaan terutama penyuluhan perikanan, bantuan peralatan dan modal usaha perlu ditingkatkan lagi.
\end{abstract}

Kata Kunci: pemberdayaan, kesejahteraan, rumah tangga, pengolahan ikan

\begin{abstract}
Empowerment of fish processors in West Java Province was carried out in order to improve wellbeing of the fish processors, ensuring food security of the product, and maintaining sustainability of the fish resource. The purpose of this study was to analyze performance of the empowerment of small scale fish processors and its related impact in the West Java Province. The analytical method used different test Man Whitney U. Hypothesis of this research was that there was a significant difference between the process of fish processing empowerment and its related impact in the north coast of Cirebon District and in the south coast of Sukabumi district of West Java Province. The results indicated that there was no significant difference between the process of fish processing empowerment and its impact both in the north coast of Cirebon and in the south coast of Sukabumi. Hence, policy on empowerment small scale fish processing household in both north and south coast districts of West Java Province can be treated the same. However, the intensity of empowerment, especially in terms of fisheries extension, equipment and business capital assistance need to be improved.
\end{abstract}

Keywords: empowerment, welfare, household, fish processing

\section{PENDAHULUAN}

Provinsi Jawa Barat memiliki dua wilayah pengelolaan perikanan yaitu laut Jawa yang terletak di bagian utara dan samudera Hindia di bagian selatan. Potensi perikanan laut dari kedua wilayah tersebut diperkirakan sebesar 1,91 juta ton/tahun (KEPMEN-KP Nomor 47/ 2016). Potensi tersebut menjadi sumber mata pencaharian masyarakat pesisir Jawa Barat yang bergantung pada ikan laut. Pemerintah pusat menyadari bahwa potensi laut yang besar harus dimanfaatkan secara optimal dengan cara meningkatkan nilai tambah produk perikanan sehingga dampak ekonomi bisa dirasakan masyarakat pesisir. Pemberdayaan pengolah ikan skala rumah tangga merupakan salah satu cara 
untuk meningkatkan ekonomi pesisir. Apabila pengolah ikan mampu mengembangkan usahanya maka nelayan dan pembudidaya ikan merasakan juga hasilnya.

Proses pemberdayaan pengolah ikan di Indonesia selama ini sering dilakukan oleh pemerintah pusat, provinsi, dan kabupaten. Pemerintah pusat, provinsi, dan kabupaten menganggap pengolah ikan kurang mampu untuk mengembangkan usahanya karena rata-rata tingkat pendidikan dan motivasi pengolah ikan di Jawa Barat tergolong rendah. Proses pemberdayaan dilakukan dengan cara memfasilitasi kebutuhan usaha melalui program pengembangan usaha mina pedesaan (PUMP).

Sebagian ahli penyuluhan dan akademisi bidang pemberdayaan menganggap hal tersebut kurang baik karena akan mengakibatkan ketergantungan masyarakat pelaku usaha terhadap bantuan. Hal ini diperkuat dengan temuan Hikmayani dan Triyanti (2015) bahwa bantuan peralatan dan modal usaha melalui program pengembangan usaha mina pedesaan (PUMP) dapat meningkatkan pendapatan tetapi menciptakan ketergantungan terhadap bantuan tersebut. Temuan lain menjelaskan bahwa kinerja program belum mampu mengurangi kemiskinan (Suryawati et al., 2013). Sementara pemerintah pusat, provinsi, dan kabupaten meyakini bahwa bantuan peralatan dan modal usaha melalui program PUMP dapat menanggulangi kemiskinan. Tujuan program tersebut akan tercapai jika dilaksanakan melalui fasilitasi penyuluhan perikanan, pengembangan peran kelompok, dan faktor lainnya (PERMEN-KP Nomor. 10/2014).

Oleh karena itu, penelitian ini bertujuan untuk:

1. menganalisis kinerja pemberdayaan pengolah ikan dan dampaknya di pesisir utara (Kabupaten Cirebon) dan pesisir selatan (Kabupaten Sukabumi) Provinsi Jawa Barat.

2. menganalisis variabel yang berperan dalam pemberdayaan pengolah ikan dan perbedaannya di pesisir utara (Kabupaten Cirebon) dan pesisir selatan (Kabupaten Sukabumi) Provinsi Jawa Barat.

\section{METODOLOGI}

\section{Lokasi dan Waktu Penelitian}

Pengumpulan dan validasi data dilakukan di Kabupaten Cirebon dan Kabupaten Sukabumi Provinsi Jawa Barat sejak bulan Oktober 2016 sampai dengan Februari 2017. Selanjutnya dilakukan analisis data dan penulisan laporan penelitian. Gambar 1 menunjukkan lokasi penelitian.

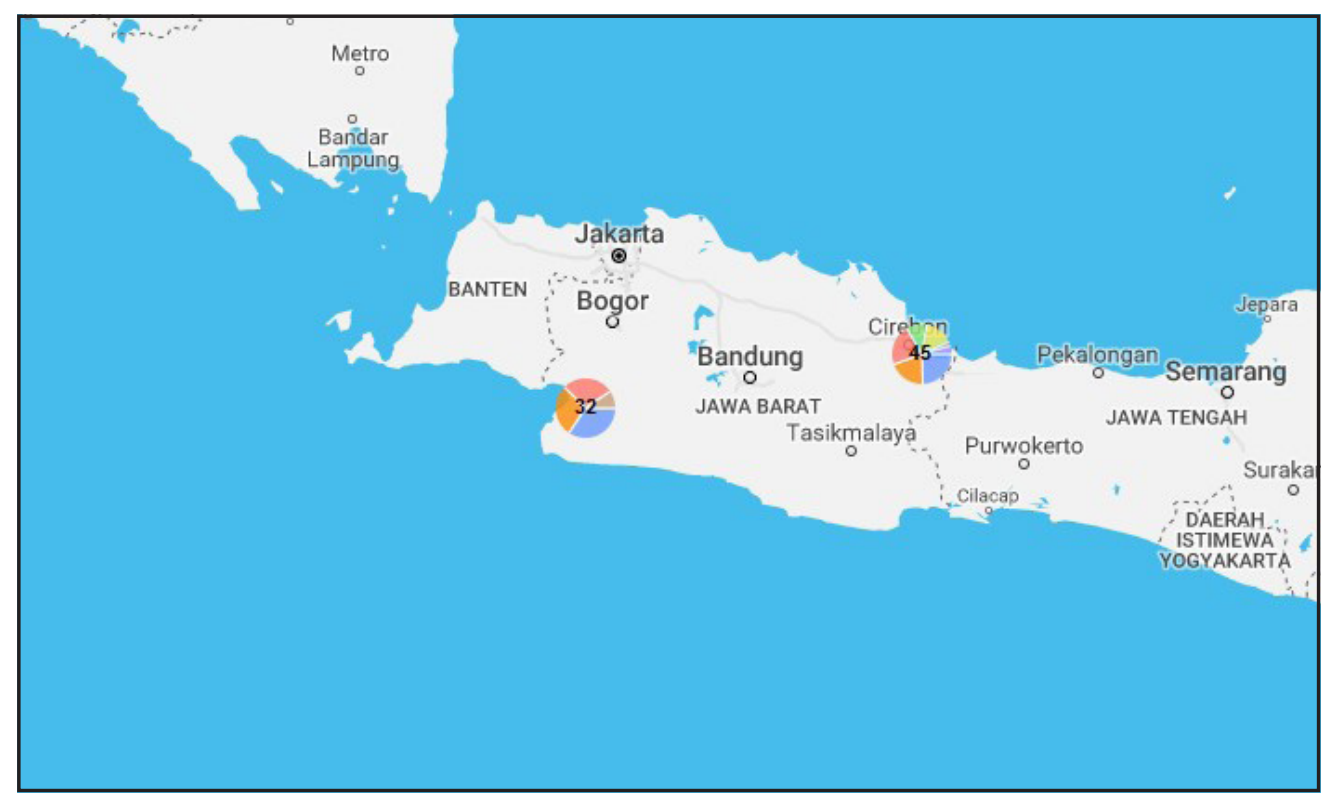

Gambar 1. Peta Lokasi Penelitian

Figure 1. Map of The Study Site 
Lokasi penelitian di Kabupaten Cirebon yaitu Kecamatan Gunungjati, Plumbon, Sumber, Suranenggala, Mundu, Pangenan, Panguragan, Beber, Jamblang, Weru, Astanajapura, dan Gebang. Lokasi penelitian di Kabupaten Sukabumi yaitu Kecamatan Pelabuhan Ratu, Cisolok, Cisaat, Ciemas, Bantargadung, Jampang Kulon, Simpenan, Citarik, Cibadak, dan Sukaraja.

\section{Metode Pengumpulan Data}

Validasi instrumen dilakukan di Kabupaten Cirebon terhadap 20 pengolah ikan. Uji instrumen dengan Cronbach's Alpha. Instrumen dengan nilai korelasi $r>0,25$ menunjukan kevalidan dan keandalan instrumen. Sementara instrumen yang memiliki nilai korelasi $<0,25$ kurang valid kemudian diperbaiki secara verbal dan substansi.

Selanjutnya dilakukan pengumpulan data di kedua lokasi terhadap 100 responden di Kabupaten Sukabumi terdiri dari 38 orang pengolah ikan asin, 22 orang pengolah pindang, 28 orang pengolah bakso ikan, 5 orang pengolah terasi, 3 orang pengolah abon ikan, dan 4 orang pengolah lainnya. Pengumpulan data di Kabupaten Cirebon terhadap 150 responden terdiri dari 24 orang pengolah ikan asin, 50 orang pengolah pindang, 12 orang pengolah baso ikan, 6 orang pengolah terasi, 5 orang pengolah abon ikan, 9 orang pengolah kerupuk ikan, 16 orang pengolah ikan asap, 10 orang pengolah rajungan, 14 orang pengolah kerang, 4 orang pengolah lainnya.

Jenis data yang dikumpulkan bersifat ordinal dan interval. Data ordinal digunakan untuk variabel yang menunjukkan tingkatan kualitas. Data interval digunakan untuk analisis parametrik dan perhitungan tetapi tidak menunjukkan tingkatan kualitas. Data interval digunakan untuk umur, tingkat pendidikan, pengalaman, dan besar keuntungan usaha.

\section{Metode Analisis Data}

Secara umum mayoritas data yang dihasilkan adalah data ordinal. Data ordinal antara 1 dan 4 kemudian diubah dalam skala interval. Indikator-indikator dalam kelompok variabel yang sama dijumlah dan dibobot antara 0 sampai dengan 100 dengan menggunakan Microsoft Excel. Selanjutnya data dianalisis dengan uji statistik komparasi Mann-Whitney U Test menggunakan aplikasi Statistic 7. Unit analisis yaitu kepala atau ibu rumah tangga yang memiliki unit pengolahan dengan bahan baku perikanan laut.
Hipotesis yang akan dibuktikan dalam penelitian ini yaitu: (1) ada perbedaan nyata tingkat keberdayaan pengolah ikan di pesisir utara (Kabupaten Cirebon) dan pesisir selatan (Kabupaten Sukabumi) Jawa Barat; (2) ada perbedaan nyata tingkat kesejahteraan pengolah ikan di pesisir utara (Kabupaten Cirebon) dan pesisir selatan (Kabupaten Sukabumi) Jawa Barat; (3) ada perbedaan nyata karakteristik dukungan internal pengolah ikan di pesisir utara (Kabupaten Cirebon) dan pesisir selatan (Kabupaten Sukabumi) Jawa Barat, dan; (4) ada perbedaan nyata karakteristik dukungan eksternal pengolah ikan di pesisir utara (Kabupaten Cirebon) dan pesisir selatan (Kabupaten Sukabumi) Jawa Barat. Hipotesis diterima apabila nilai perbedaan signifikan $\mathrm{P}<0,05$ tetapi ditolak jika nilai $P>0,05$ artinya tidak ada perbedaan nyata. Data disajikan dalam bentuk tabulasi.

\section{HASIL DAN PEMBAHASAN}

\section{Dampak Pemberdayaan Pengolah Ikan Skala Rumah Tangga di Provinsi Jawa Barat}

Dampak pemberdayaan sangat dipengaruhi oleh orang yang berasal dari luar sistem atau agen perubahan (Lippitt, 1953). Tingkat keberdayaan rumah tangga pengolah ikan di pesisir utara (Kabupaten Cirebon) dan pesisir selatan (Kabupaten Sukabumi) tidak berbeda dan termasuk tinggi. Tabel 1 menunjukkan tidak ada perbedaan tingkat keberdayaan rumah tangga pengolah ikan sesuai hasil uji man whitney $U$ test dengan nilai $p>0,05$. Hipotesis penelitian ke- 1 yaitu "ada perbedaan nyata tingkat keberdayaan rumah tangga pengolah ikan di pesisir utara (Kabupaten Cirebon) dan pesisir selatan (Kabupaten Sukabumi) Provinsi Jawa Barat" ditolak.

Besar keuntungan usaha di pesisir utara (Kabupaten Cirebon) rata-rata hanya 2,50 juta rupiah dan di pesisir selatan (Kabupaten Sukabumi) rata-rata 3,60 juta rupiah. Jika disetarakan dengan upah minimum regional provinsi Jawa Barat yang rata-rata 2 juta rupiah per bulan maka keuntungan usaha pengolah ikan di pesisir utara dan selatan sudah di atas upah minimum. Penghitungan keuntungan didasari oleh data keuntungan minimal dan maksimal per trip operasi dikalikan dengan jumlah trip dalam sebulan.

Operasi pengolahan ikan dalam sebulan berbeda-beda bergantung pada jenis pengolahannya. Pengolah di pesisir utara 
(Kabupaten Cirebon) dalam sebulan mampu mengolah produk abon 10 kali, ikan asap 24 kali, bakso 22 kali, ikan asin 17 kali, kerang kupas 22 kali, kerupuk ikan 15 kali, pindang 27 kali, rajungan kupas 27 kali, dan terasi 18 kali. Pengolah ikan di pesisir utara (Kabupaten Cirebon) bersifat harian dengan kebutuhan bahan baku 20-50 kilogram per trip. Sementara pengolah ikan di pesisir selatan (Kabupaten Sukabumi) dapat mengolah produk dalam sebulan yaitu abon 5 kali, baso ikan 18 kali, ikan asin 2 kali, pindang 3 kali, dan terasi 3 kali. Pengolah ikan di pesisir selatan (Kabupaten Sukabumi) bersifat mingguan kecuali baso ikan.

Selain itu, keberdayaan pengolah ikan skala rumah tangga di pesisir utara (Kabupaten Cirebon) dan pesisir selatan (Kabupaten Sukabumi) sangat bergantung pada kapasitasnya. Kapasitas adalah kemampuan individu atau organisasi dalam menjalankan fungsi-fungsinya secara efektif, efisien, berkelanjutan (Milen, 2001), dan berorientasi jangka panjang (Rubzen dan Burgess, 2016). Kapasitas pengolah ikan di pesisir selatan (Kabupaten Sukabumi) dan di pesisir utara (Kabupaten Cirebon) termasuk tinggi. Indikator tersebut dilihat dari kelayakan pengolahan ikan, keramahan lingkungan, dan kemampuan manajerial.

Perilaku dalam mengolah ikan di kedua wilayah termasuk baik. Kelayakan pengolahan dinilai dari tempat dan peralatan yang higienis dengan ketentuan jauh dari lokasi pembuangan sampah atau kandang ternak. Selain itu, peralatan yang terbuat dari bahan tahan karat. Perilaku lainnya yang mendukung kelayakan yaitu tidak menggunakan pengawet berbahaya, mencuci tangan sebelum bekerja, dan tidak meludah sembarangan. Perilaku mengolah yang masih perlu ditingkatkan yaitu penggunaan penutup kepala saat mengolah ikan, di pesisir utara (Kabupaten Cirebon) pengolah ikan jarang menggunakan topi sedangkan di pesisir selatan (Kabupaten Sukabumi) cenderung sering memakai topi saat mengolah ikan.

Sikap ramah lingkungan di kedua wilayah ditunjukkan dengan penggunaan air bersih sesuai keperluan dan menutup keran secara disiplin saat tidak digunakan lagi. Selain itu, sikap ramah lingkungan lainnya yaitu segera mematikan lampu saat tidak dibutuhkan, sampah dibuang secara teratur, dan tidak mengolah ikan yang dilindungi oleh pemerintah. Tabel 1. Persentase Responden Berdasarkan Kategori Indikator Tingkat Keberdayaan di Lokasi
Penelitian.

Table 1. Percentage of Respondents by Category of The Level Empowerment Indicators in the Study Site.

\begin{tabular}{|c|c|c|c|c|}
\hline Indikator/ Indicators & Kategori/ Category & Cirebon (\%) & Sukabumi (\%) & Sig uji $(U)^{1}$ \\
\hline $\begin{array}{l}\text { Keuntungan usaha/ } \\
\text { Business profits (Rupiah) }\end{array}$ & $\begin{array}{c}\text { Rendah/ low }(\leq 2 \mathrm{jt} / \text { million }) \\
\text { Sedang/ medium }(2>\mathrm{x} \leq 4 \mathrm{jt} / \text { million }) \\
\text { Tinggi/ High }(>4 \mathrm{jt} / \text { million })\end{array}$ & $\begin{array}{l}54.00 \\
33.34 \\
12.66\end{array}$ & $\begin{array}{l}18.00 \\
46.00 \\
36.00\end{array}$ & 1.00 \\
\hline Rataan/Average & & $2.50 \mathrm{jt}$ & $3.60 \mathrm{jt}$ & \\
\hline $\begin{array}{l}\text { Kelayakan pengolahan/ } \\
\text { Good processing } \\
\text { Rataan/Average }{ }^{2)}\end{array}$ & $\begin{array}{c}\text { Rendah/ low }(0-50) \\
\text { Sedang/ medium }(51-75) \\
\text { Tinggi/ high }(76-100)\end{array}$ & $\begin{array}{r}0.00 \\
14.00 \\
86.00 \\
82.73\end{array}$ & $\begin{array}{r}0.00 \\
4.00 \\
96.00 \\
90.10\end{array}$ & 0.65 \\
\hline $\begin{array}{l}\text { Ramah lingkungan/ } \\
\text { Environmentally friendly }\end{array}$ & $\begin{array}{l}\text { Rendah/ low }(0-50) \\
\text { Sedang/ medium }(51-75) \\
\text { Tinggi/ high }(76-100)\end{array}$ & $\begin{array}{r}0.00 \\
12.66 \\
87.34 \\
81.45\end{array}$ & $\begin{array}{r}0.00 \\
3.00 \\
97.00 \\
85.81\end{array}$ & 0.77 \\
\hline Manajerial/Managerial & $\begin{array}{l}\text { Rendah/ low }(0-50) \\
\text { Sedang/ medium }(51-75) \\
\text { Tinggi/ high }(76-100)\end{array}$ & $\begin{array}{l}17.34 \\
58.00 \\
24.66\end{array}$ & $\begin{array}{r}1.00 \\
59.00 \\
40.00\end{array}$ & 0.73 \\
\hline Rataan/Average ${ }^{2)}$ & & 65.46 & 74.95 & \\
\hline $\begin{array}{l}\text { Posisi tawar/Bargaining } \\
\text { position }\end{array}$ & $\begin{array}{l}\text { Rendah/ low }(0-50) \\
\text { Sedang/ medium }(51-75) \\
\text { Tinggi/ high }(76-100)\end{array}$ & $\begin{array}{l}31.34 \\
44.66 \\
24.00\end{array}$ & $\begin{array}{l}51.00 \\
20.00 \\
29.00\end{array}$ & 0.55 \\
\hline Rataan/ average ${ }^{2)}$ & & 64.66 & 61.75 & \\
\hline
\end{tabular}


Lanjutan Tabel 1/Continue Table 1

\begin{tabular}{|c|c|c|c|c|}
\hline Indikator/ Indicators & Kategori/ Category & Cirebon (\%) & Sukabumi (\%) & Sig uji (U) ${ }^{1}$ \\
\hline Kreativitas/Creativity & $\begin{array}{c}\text { Rendah/ low }(0-50) \\
\text { Sedang/ medium }(51-75) \\
\text { Tinggi/ high }(76-100)\end{array}$ & $\begin{array}{r}92.00 \\
4.00 \\
4.00\end{array}$ & $\begin{array}{r}69.00 \\
30.00 \\
1.00\end{array}$ & 0.92 \\
\hline Rataan/Average 2) & & 37.27 & 45.75 & \\
\hline Jumlah/Total & $\begin{array}{c}\text { Rendah/ low }(0-50) \\
\text { Sedang/ medium }(51-75) \\
\text { Tinggi/ high }(76-100)\end{array}$ & $\begin{array}{r}9.33 \\
78.00 \\
12.67\end{array}$ & $\begin{array}{r}0.00 \\
72.00 \\
28.00\end{array}$ & s1.00 \\
\hline Rataan/Average ${ }^{2)}$ & & 63.93 & 72.61 & \\
\hline
\end{tabular}

Sumber: Data primer diolah (2017)/ Source: Primary Data Processed (2017)

Keterangan/ Remarks: $\mathrm{n}$ Cirebon $=150 ; \mathrm{n}$ Sukabumi $=100$

1 *nyata/significant $\mathrm{P}<0,05$

2 rataan skor/score average: rendah/ low $=0-50$, sedang/ medium $=51-75$, tinggi $/$ high $=76-100$

Sikap ramah lingkungan lainnya yang perlu ditingkatkan di kedua wilayah yaitu perilaku dalam penggunaan tangki penampung air, penanganan limbah cair, dan penggunaan ulang kemasan yang masih layak pakai. Pengunaan tangki dapat menghemat energi listrik tapi faktanya masih banyak yang belum menggunakan tangki air bahkan tidak niat untuk memakainya padahal kebutuhan debit air bersih dalam mengolah ikan besar. Di samping itu, pembuangan limbah cair di kedua wilayah secara umum masih langsung ke saluran tanpa diperlakukan dengan baik. Pengolah ikan di kedua wilayah juga masih boros dalam menggunakan kemasan kardus atau plastik dan belum mampu menggunakan kembali kemasan yang masih layak.

Kapasitas manajerial dalam mengelola usaha di kedua wilayah masih termasuk kategori sedang yang diukur dari perencanaan produksi, pengelolaan tenaga kerja, dan keuangan. Pengelolaan pekerjaan di kedua wilayah dalam kategori baik. Pengolah ikan dapat mengatur orang sesuai pekerjaannya atau bebas bekerja tapi sesuai dengan tahapan pekerjaan. Kapasitas mengelola keuangan di kedua wilayah juga sangat baik. Pengolah ikan mampu mencatat transaksi jual beli dalam buku baik pembelian bahan baku maupun penjualan produk. Selain itu, pengolah ikan juga secara umum sudah mampu memisahkan uang modal usaha dan kebutuhan sehari-hari.

Kapasitas manajerial yang berbeda di kedua wilayah yaitu dalam perencanaan produksi dan pengelolaan upah kerja. Perencanaan produksi di pesisir selatan (Kabupaten Sukabumi) kurang baik. Pengolah ikan di pesisir selatan mengolah ikan apa saja yang ada di tempat pelelangan ikan tidak ada perencanaan waktu. Sebaliknya di pesisir utara (Kabupaten Cirebon), operasi mengolah ikan bergantung pada pesanan dari pembeli. Namun, upah tenaga kerja di pesisir utara secara umum dibayar sesukanya karena masih kerabat atau anggota keluarga sedangkan di pesisir selatan, secara umum upah kerja dibayar borongan sesuai volume kerja.

Tingkat posisi tawar di kedua wilayah tidak ada perbedaan yang signifikan. Posisi tawar terhadap pemasok bahan baku di kedua wilayah termasuk rendah. Pengolah ikan cenderung tetap membeli bahan baku berapa pun harganya. Sementara, posisi tawar terhadap pedagang produk dan konsumen di kedua wilayah juga rendah. Pengolah ikan tetap menjual produk meskipun harganya murah.

Tingkat kreativitas pengolah ikan di kedua wilayah sangat rendah. Pengolah ikan hanya sebatas memberikan potongan harga kepada pelanggan, sedangkan kreativitas dalam membuat produk kualitas super, kemasan produk yang menarik, menjual produk ke toko oleh-oleh, promosi secara online, dan partisipasi pameran produk di kedua wilayah masih rendah.

Tingkat kesejahteraan di kedua wilayah termasuk dalam kategori tinggi. Tidak ada perbedaan kesejahteran rumah tangga pengolah ikan di kedua wilayah. Sesuai dengan penelitian Muflikhati et al. (2010) bahwa tidak ada perbedaan tingkat kesejahteraan di pesisir utara (Kabupaten Cirebon) dan selatan (Kabupaten Sukabumi) Jawa Barat. Oleh karena itu, hipotesis penelitian ke-2 yaitu "ada perbedaan tingkat kesejahteraan di pesisir utara (Kabupaten Cirebon) dan pesisir selatan (Kabupaten Sukabumi) Provinsi Jawa Barat" ditolak. 
Tabel 2 menunjukkan karakteristik luas rumah, sanitasi, daya listrik, dan kepemilikan barang di kedua wilayah tidak ada perbedaan signifikan $(P>0,05)$. Namun, ada perbedaan pada kualitas dinding rumah $(P<0,05)$. Dinding rumah pengolah ikan di pesisir utara (Kabupaten Cirebon) mayoritas berbahan tembok, sedangkan di pesisir selatan (Kabupaten Sukabumi) 20 persen rumah berdinding kayu dan bambu.

Luas lantai rumah per kapita di kedua wilayah sangat memadai atau lebih dari $8 \mathrm{~m}^{2}$ per kapita. Rata-rata luas rumah pengolah ikan dan masyarakat pedesaan Jawa Barat berukuran $80 \mathrm{~m}^{2}$. Lantai rumah umumnya terbuat dari keramik. Rumah yang luas menjadi kebanggaan masyarakat terutama dapur yang luas dapat digunakan sebagai tempat memasak, gudang, dan sekaligus tempat makan dan berkumpulnya anggota keluarga di siang hari.
Kondisi sanitasi di kedua wilayah sangat baik dengan jamban sendiri meskipun masih ada yang menggunakan jamban bersama khususnya di pesisir selatan (Kabupaten Sukabumi). Daya listrik di kedua wilayah rata-rata 900 - 1300 watt, namun di pesisir utara (Kabupaten Cirebon) masih banyak rumah dengan daya listrik 450 watt.

Tingkat kepemilikan barang di kedua wilayah sama. Pengolah ikan rata-rata memiliki televisi, kulkas, sepeda motor, dan kursi tamu. Kursi tamu dimasukkan dalam penghitungan kepemilikan barang karena barang ini menjadi barang mewah dan menjadi kebanggaan rumah tangga di perdesaan Jawa Barat. Rumah tangga yang memilki kursi tamu menandakan rumah yang luas sehingga ruang tamu berukuran luas. Pengolah ikan yang memiliki mobil di kedua wilayah hanya sebagian kecil saja atau kurang dari 10 persen. Mobil masih termasuk barang mewah dan menjadi kebanggaan bagi masyarakat.

Tabel 2. Persentase Responden Berdasarkan Kategori Indikator Tingkat Kesejahteraan di Lokasi Penelitian.

Table 2. Persentage of Respondent by Category of The Level Welfare Indicators in the Study Site.

\begin{tabular}{|c|c|c|c|c|}
\hline Indikator/Indicators & Kategori/Category & $\begin{array}{c}\text { Cirebon } \\
(\%)\end{array}$ & $\begin{array}{l}\text { Sukabumi } \\
(\%)\end{array}$ & Sig uji $U^{1}$ \\
\hline \multirow{3}{*}{$\begin{array}{l}\text { Kualitas dinding rumah/ } \\
\text { Quality walls of the } \\
\text { house (skor/score) }\end{array}$} & Rusak/Bad(2-4) & 0.00 & 0,00 & \multirow[t]{3}{*}{$0,01^{*}$} \\
\hline & Baik/Good (5-6) & 100.00 & 95,00 & \\
\hline & Sangat baik/Very good (7) & 0.00 & 5,00 & \\
\hline \multirow{2}{*}{$\begin{array}{l}\text { Luas lantai rumah per } \\
\text { kapita/ House floor per } \\
\text { capita }\left(\mathrm{m}^{2}\right)\end{array}$} & Kurang/Inadequate $(<8)$ & 2.00 & 2,00 & \multirow[t]{2}{*}{0,08} \\
\hline & Memadai/Adequate $(\geq 8)$ & 98.00 & 98,00 & \\
\hline \multirow{3}{*}{$\begin{array}{l}\text { Kondisi sanitasi/ The } \\
\text { sanitary conditions } \\
\text { (skor/score) }\end{array}$} & Jamban umum/ Public toilet (1-2) & 0.00 & 0.00 & \multirow[t]{3}{*}{0.86} \\
\hline & Jamban bersama/Joint toilet (3) & 0.67 & 3.00 & \\
\hline & Jamban sendiri/ Own latrines (4) & 99.33 & 97.00 & \\
\hline \multirow{3}{*}{$\begin{array}{l}\text { Daya listrik/ Electrical } \\
\text { power (watt) }\end{array}$} & Rendah/Low $(<900)$ & 42.00 & 0.00 & \multirow[t]{3}{*}{0.98} \\
\hline & Sedang/Medium (900 - 1300) & 56.66 & 99.00 & \\
\hline & Tinggi/High (> 1300) & 1.34 & 1.00 & \\
\hline \multirow{4}{*}{$\begin{array}{l}\text { Kepemilikan barang } \\
\text { rumah tangga/ } \\
\text { Ownership of } \\
\text { household goods (skor/ } \\
\text { score) }\end{array}$} & Rendah/Low (1-2) & 4.00 & 3.00 & \multirow[t]{3}{*}{0.91} \\
\hline & Sedang/Medium $(3-4)$ & 88.00 & 90.00 & \\
\hline & Tinggi/High (5) & 8.00 & 7.00 & \\
\hline & Rendah/Low $(0-50)$ & 0.00 & 0.00 & \multirow[t]{3}{*}{0.97} \\
\hline \multirow[t]{2}{*}{ Jumlah/Total } & Sedang/Medium (51 - 75) & 10,00 & 10.00 & \\
\hline & Tinggi/High $(76-100)$ & 90.00 & 90.00 & \\
\hline
\end{tabular}

Sumber: Data primer diolah (2017)/Source: Primary Data Processed (2017)

Keterangan/Note: $\mathrm{n}$ Cirebon $=150 ; \mathrm{n}$ Sukabumi $=100$

1 *nyata/significant $\mathrm{P}<0,05$

2 rataan skor/score average: rendah/low $=0-50$, sedang $/$ medium $=51-75$, tinggi $/$ high $=76-100$ 


\section{Variabel Pemberdayaan Pengolah Ikan Skala Rumah Tangga di Provinsi Jawa Barat}

Karakteristik individu dan dukungan eksternal mempengaruhi keberdayaan masyarakat petani (Sadono, 2012; Rayuddin, 2010), nelayan (Soepratikno, 2015), pembudidaya ikan (Fatchiya, 2010), dan pengusaha kecil (Arevin, 2014). Variabel pemberdayaan pengolah ikan terdiri dari dukungan internal dan eksternal. Dukungan internal yaitu karakteristik pengolah ikan, motivasi, dan kekuatan jaringan usaha. Dukungan internal di pesisir utara (Kabupaten Cirebon) dan pesisir selatan (Kabupaten Sukabumi) Jawa Barat tidak ada perbedaan setelah diuji dengan man whitney $U$ test dengan rata-rata nilai $P>0,05$ (Tabel 3). Oleh karena itu, hipotesis penelitian ke-3 yaitu "ada perbedaan nyata dukungan internal dalam pemberdayaan rumah tangga pengolah ikan di pesisir utara dan selatan provinsi Jawa Barat" ditolak.

Pengolah ikan skala rumah tangga di pesisir utara (Kabupaten Cirebon) rata-rata berumur 44 tahun sedangkan di pesisir selatan (Kab. Sukabumi) rata-rata berumur 48 tahun. Pengolah ikan di Jawa Barat sebagian besar berusia dewasa pertengahan antara 31 - 60 tahun. Fase dewasa pertengahan berperan dalam membimbing anakanaknya menjadi orang dewasa, menjaga kepuasan kinerja dalam pekerjaannya, membangun aktivitas di waktu senggang, membangun hubungan yang saling mendukung dengan pasangan hidup, dan menyesuaikan perubahan fisik yang terjadi dengan pekerjaannya (Havighurst, 1972). Fase ini juga dikatakan usia produktif (Rusli, 1995).

Tabel 3. Persentase Responden Berdasarkan Kategori Indikator Karakteristik Pengolah Ikan di Lokasi Penelitian.

Table 3. Percentage of Respondents by Category of of Fish Processing Characteristics Indicators in the Study Site.

\begin{tabular}{|c|c|c|c|c|}
\hline Indikator/Indicators & Kategori/ Category & $\begin{array}{c}\text { Cirebon } \\
(\%)\end{array}$ & $\begin{array}{c}\text { Sukabumi } \\
(\%)\end{array}$ & $\begin{array}{l}\text { Sign } \\
\text { (uji U) }\end{array}$ \\
\hline \multirow[t]{3}{*}{ Umur/Age (tahun/year) } & $18-30$ & 8.67 & 1.00 & 0.17 \\
\hline & $31-60$ & 83.33 & 94.0 & \\
\hline & $61-72$ & 9.50 & 5.0 & \\
\hline Rataan/Average & & 44 & 48 & \\
\hline $\begin{array}{l}\text { Pendidikan/ Education (tahun/ } \\
\text { Year) }\end{array}$ & $\begin{array}{r}0-6 \\
7-12 \\
13-17\end{array}$ & $\begin{array}{r}53.33 \\
44.00 \\
2.67\end{array}$ & $\begin{array}{r}61.00 \\
38.00 \\
1.00\end{array}$ & 0.22 \\
\hline Rataan/Average & & 8 & 7 & \\
\hline $\begin{array}{l}\text { Pengalaman/ Experience (tahun/ } \\
\text { Year) }\end{array}$ & $\begin{array}{r}1-5 \\
6-20 \\
21-52\end{array}$ & $\begin{array}{l}29.33 \\
59.33 \\
11.34\end{array}$ & $\begin{array}{l}14.00 \\
66.00 \\
20.00\end{array}$ & 0.87 \\
\hline Rataan/ Average & & 12 & 15 & \\
\hline $\begin{array}{l}\text { Jumlah tanggungan rumah } \\
\text { tangga/ Number of household } \\
\text { members (orang/Person) }\end{array}$ & $\begin{array}{r}1-3 \\
4-7 \\
8-10\end{array}$ & $\begin{array}{r}24.67 \\
71.33 \\
4.00\end{array}$ & $\begin{array}{r}3.00 \\
94.00 \\
3.00\end{array}$ & 0.73 \\
\hline Rataan/Average & & 4 & 5 & \\
\hline $\begin{array}{l}\text { Motivasi usaha/Business } \\
\text { motivation }\end{array}$ & $\begin{array}{l}\text { Rendah/Low }(0-50) \\
\text { Sedang/Medium }(51-75) \\
\text { Tinggi/High }(76-100)\end{array}$ & $\begin{array}{r}8.67 \\
90.00 \\
1.33\end{array}$ & $\begin{array}{r}3.00 \\
87.00 \\
10.00\end{array}$ & 0.73 \\
\hline Rataan/Average ${ }^{2)}$ & & 63.58 & 66.62 & \\
\hline $\begin{array}{l}\text { Kekuatan jaringan usaha/ } \\
\text { Strength of business network } \\
\text { Rataan/Average }{ }^{2)}\end{array}$ & $\begin{array}{c}\text { Rendah/Low }(0-50) \\
\text { Sedang/Medium }(51-75) \\
\text { Tinggi/High }(76-100)\end{array}$ & $\begin{array}{r}0.70 \\
52.85 \\
46.45 \\
75.67\end{array}$ & $\begin{array}{r}8.00 \\
58.00 \\
34.00 \\
68.43\end{array}$ & 0.75 \\
\hline
\end{tabular}

Sumber: Data primer diolah (2017)/Source: Primary Data Processed (2017)

Keterangan/Note: $\mathrm{n}$ Cirebon = 150; $\mathrm{n}$ Sukabumi $=100$

1 *nyata/significant $\mathrm{P}<0,05$

${ }^{2}$ rataan skor/score average: rendah $/$ low $=0-50$, sedang $/$ medium $=51-75$, tinggi $/$ high $=76-100$ 
Selain itu, tingkat pendidikan harus dipertimbangkan dalam proses pemberdayaan. Pengolah ikan skala rumah tangga di kedua wilayah rata-rata berpendidikan rendah dengan lama sekolah rata-rata $7-8$ tahun. Tingkat pendidikan di pesisir utara rata-rata berpendidikan menengah tetapi tidak sedikit pengolah ikan yang tidak tamat sekolah dasar, sedangkan tingkat pendidikan di pesisir selatan (Kabupaten Sukabumi) rata-rata berpendidikan sekolah dasar. Pendidikan sebagai modal untuk merubah perilaku yang lebih baik (Robbins, 2003). Apabila tingkat kreativitas pengolah ikan di Jawa Barat rendah maka sudah sewajarnya karena tingkat pendidikannya rata-rata rendah.

Umur dan pendidikan diduga mempengaruhi tingkat keinovatifan seseorang. Di samping itu, pengalaman usaha juga perlu dipertimbangkan dalam pemberdayaan. Pengalaman usaha pengolah ikan di Jawa Barat termasuk sedang antara 6 - 20 tahun dengan rata-rata lama usaha 12 tahun di pesisir utara (Kabupaten Cirebon) dan 15 tahun di pesisir selatan (Kabupaten Sukabumi). Hal ini sebanding dengan rata-rata umur di kedua wilayah tersebut.

Pengalaman diperoleh dari hasil pengamatan perilaku atau meniru orang lain (Bandura, 1977). Seperti halnya sebagian besar pengolah ikan yang melanjutkan usaha orang tuanya tetapi pengelolaan usaha tetap harus sesuai dengan kemajuan teknologi, keinginan pasar, dan kondisi bahan baku.

Jumlah tanggungan rumah tangga pengolah ikan di Jawa Barat rata-rata antara $4-7$ orang yang terdiri dari kepala rumah tangga, ibu rumah tangga, dan anggota rumah tangga. Jumlah tanggungan rumah tangga di pesisir utara (Kabupaten Cirebon) rata-rata 4 orang per unit rumah tangga dan di pesisir selatan (Kabupaten Sukabumi) rata-rata 5 orang per unit rumah tangga.

Dukungan internal lainnya yang mempengaruhi keberdayaan pengolah ikan yaitu motivasi usaha. Tingkat motivasi usaha pengolah ikan di Jawa Barat tergolong sedang dengan skor antara 51 persen sampai dengan 75 persen. Motivasi pengolah ikan di Jawa Barat yaitu memenuhi kebutuhan hidup sehari-hari dan melanjutkan usaha keluarga yang sudah turun temurun. Kondisi ini menjadi zona nyaman bagi sebagian besar pengolah ikan skala rumah tangga. Pengolah ikan merasa puas dengan terpenuhinya kebutuhan hidup sehari-hari tetapi merasakan kebosanan dalam usahanya. Zona nyaman cenderung mengakibatkan resisten terhadap perubahan (Tracy, 2012). Untuk keluar dari zona nyaman perlu tantangan dan pengenalan jenisjenis keterampilan baru (Borbye, 2010).

Motivasi usaha berhubungan dengan pemenuhan kebutuhan hidup (Maslow 1954 dan Frager 1987) yang berasal dari dalam dan luar individu (Sumardjo 1999). Motivasi pengolah ikan skala rumah tangga di Jawa Barat yaitu: (1) keinginan melanjutkan usaha orang tua atau keluarga yang sudah turun temurun, (2) merasakan pendapatan yang memadai untuk memenuhi kebutuhan hidup sehari-hari, (3) keinginan mengikuti kesuksesan orang lain dalam usaha pengolahan ikan, (4) merasakan kesulitan mencari pekerjaan dan usaha selain pengolah ikan, (5) keinginan membantu ekonomi keluarga atau suami, (6) merasakan kemudahan akses bahan baku ikan laut, (7) merasakan tingginya permintaan produk olahan ikan atau kemudahan pemasaran, (8) merasakan percaya diri karena usaha dari kecil dan punya keahlian, (9) merasakan ada peluang dari tetangga yang berusaha sebagai nelayan atau bakul ikan, (10) merasakan dekat dengan laut yang berpotensi besar, (11) merasakan peluang besar karena masih jarang dilakukan orang lain, (12) keinginan menjadi pengusaha sukses, (13) keinginan mencoba usaha pengolahan ikan, (14) merasa percaya diri karena memiliki pengalaman kerja di tempat pengolahan ikan, dan (15) keinginan membantu orang lain mendapatkan pekerjaan.

Interaksi sosial dalam usaha pengolahan ikan sebagai modal sosial dalam meningkatkan keberdayaan. Tingkat rasa percaya (level of trust) dengan mitra usaha baik sesama pengolah ikan, pemasok bahan baku maupun pedagang pengumpul atau pengecer sebagai bentuk kekuatan jaringan usaha.

Kekuatan jaringan usaha pengolahan ikan di Jawa Barat rata-rata termasuk kategori sedang dengan skor antara 51 persen sampai dengan 75 persen. Pengolah ikan di kedua wilayah mempercayai nilai-nilai kejujuran sebagian besar pemasok bahan baku, pedagang produk, dan sesama pengolah ikan.

Sebagian ahli sosial berpendapat bahwa tingkat rasa percaya sebagai bagian dari modal sosial dijadikan sebagai indikator keberdayaan artinya semakin besar rasa percaya terhadap 
Tabel 4. Persentase Responden Berdasarkan Kategori Indikator Dukungan Eksternal di Lokasi Penelitian.

Table 4. Percentage of Respondents by Category of External Support Indicators in the Study Site.

\begin{tabular}{|c|c|c|c|c|}
\hline Indikator/ Indicators & Kategori/ Category & $\begin{array}{c}\text { Cirebon } \\
(\%)\end{array}$ & $\begin{array}{l}\text { Sukabumi } \\
(\%)\end{array}$ & $\begin{array}{c}\text { Sig } \\
\text { uji (U) }{ }^{1}\end{array}$ \\
\hline \multirow{3}{*}{$\begin{array}{l}\text { Peran pemerintah/ } \\
\text { The role of government }\end{array}$} & Rendah/Low $(0-50)$ & 93.33 & 89.00 & 0.05 \\
\hline & Sedang/Medium ( $51-75)$ & 5.33 & 3.00 & \\
\hline & Tinggi/High $(76-100)$ & 1.37 & 8.00 & \\
\hline Rataan/Average ${ }^{2)}$ & & 17.79 & 21.73 & \\
\hline $\begin{array}{l}\text { Penyuluhan perikanan/ } \\
\text { Fisheries extension }\end{array}$ & $\begin{array}{c}\text { Rendah/Low }(0-50) \\
\text { Sedang/Medium }(51-75) \\
\text { Tinggi/High }(76-100)\end{array}$ & $\begin{array}{r}71.33 \\
20.00 \\
8.67\end{array}$ & $\begin{array}{r}55.00 \\
37.00 \\
8.00\end{array}$ & 0.51 \\
\hline Rataan/Average ${ }^{2}$ & & 40.04 & 48.25 & \\
\hline $\begin{array}{l}\text { Peran kelompok pengolah/ } \\
\text { The role of processing } \\
\text { group }\end{array}$ & $\begin{array}{c}\text { Rendah/Low }(0-50) \\
\text { Sedang/Medium }(51-75) \\
\text { Tinggi/High }(76-100)\end{array}$ & $\begin{array}{l}61.33 \\
18.66 \\
20.01\end{array}$ & $\begin{array}{l}36.00 \\
34.00 \\
30.00\end{array}$ & 0.95 \\
\hline Rataan/Average ${ }^{2}$ & & 53.75 & 65.87 & \\
\hline Permodalan/Capital & $\begin{array}{c}\text { Rendah/Low }(0-50) \\
\text { Sedang/Medium }(51-75) \\
\text { Tinggi/High }(76-100)\end{array}$ & $\begin{array}{r}87.33 \\
10.00 \\
2.67\end{array}$ & $\begin{array}{r}96.00 \\
4.00 \\
0.00\end{array}$ & 0.74 \\
\hline Rataan/Average ${ }^{2)}$ & & 24.70 & 21.80 & \\
\hline Pasar/Market & $\begin{array}{c}\text { Rendah/Low }(0-50) \\
\text { Sedang/Medium }(51-75) \\
\text { Tinggi/High }(76-100)\end{array}$ & $\begin{array}{r}78.66 \\
2.66 \\
18.68\end{array}$ & $\begin{array}{l}56.00 \\
24.00 \\
20.00\end{array}$ & 0.20 \\
\hline Rataan/Average ${ }^{2)}$ & & 50.88 & 54.66 & \\
\hline Bahan baku/ Raw material & $\begin{array}{c}\text { Rendah/Low }(0-50) \\
\text { Sedang/Medium }(51-75) \\
\text { Tinggi/High }(76-100)\end{array}$ & $\begin{array}{r}8.66 \\
90.00 \\
1.34\end{array}$ & $\begin{array}{r}52.00 \\
48.00 \\
0.00\end{array}$ & $0.03^{*}$ \\
\hline Rataan/Average ${ }^{2}$ & & 70.17 & 53.87 & \\
\hline Sarana/Tools & $\begin{array}{c}\text { Rendah/Low }(0-50) \\
\text { Sedang/Medium }(51-75) \\
\text { Tinggi/High }(76-100)\end{array}$ & $\begin{array}{r}0.00 \\
14.66 \\
85.34\end{array}$ & $\begin{array}{r}0.00 \\
35.00 \\
65.00\end{array}$ & 0.57 \\
\hline Rataan/Average ${ }^{2}$ & & 82.62 & 83.68 & \\
\hline Prasarana/ Infrastructure & $\begin{array}{c}\text { Rendah/Low }(0-50) \\
\text { Sedang/Medium }(51-75) \\
\text { Tinggi/High }(76-100)\end{array}$ & $\begin{array}{r}0.00 \\
5.33 \\
94.67\end{array}$ & $\begin{array}{r}1.00 \\
35.00 \\
64.00\end{array}$ & 0.14 \\
\hline Rataan/Average 2 ) & & 93.77 & 85.66 & \\
\hline Jumlah/Total & $\begin{array}{c}\text { Rendah/Low }(0-50) \\
\text { Sedang/Medium }(51-75) \\
\text { Tinggi/High }(76-100)\end{array}$ & $\begin{array}{r}35.33 \\
58.00 \\
6.67\end{array}$ & $\begin{array}{l}39.00 \\
50.00 \\
11.00\end{array}$ & 1.00 \\
\hline Rataan/Average $^{2}$ & & 53.85 & 54.80 & \\
\hline
\end{tabular}

Sumber: Data primer diolah (2017)/ Source: Primary Data Processed (2017)

Keterangan/Note: $\mathrm{n}$ Cirebon $=150 ; \mathrm{n}$ Sukabumi $=100$

${ }^{1}$ *nyata/significant $\mathrm{P}<0,05$

${ }^{2}$ rataan skor/score average: rendah/low $=0-50$, sedang $/$ medium $=51-75$, tinggi $/$ high $=76-100$ 
mitra usaha maka semakin besar tingkat keberdayaannya. Tingkat rasa percaya yang tinggi dapat meningkatkan keberhasilan ekonomi (Fukuyama, 1995), kesejahteraan yang lebih baik (Halpern, 2005), dan kesempatan kerja (Granovetter, 1973). Kekuatan jaringan usaha sebagai modal sosial pengolah ikan di Jawa Barat yaitu: (1) intensitas komunikasi dengan mitra usaha, (2) persatuan kelompok yang lebih kuat, (3) kedekatan rumah, kerabat, dan rasa kekeluargaan (4) kesamaan sumber bahan baku dan desa pengolah, (5) keterikatan anggota koperasi, (6) saling membantu dan menguntungkan, (7) menjaga kualitas produk, (8) saling berbagi informasi pasar, (9) kesepakatan harga yang sesuai, dan (10) komitmen dan keterikatan usaha.

Dukungan eksternal dalam pemberdayaan pengolah ikan skala rumah tangga di Jawa Barat yaitu peran pemerintah, penyuluhan perikanan, peran kelompok pengolah ikan, permodalan, pasar, bahan baku, sarana, dan prasarana (Tabel 4). Dukungan eksternal di kedua wilayah tidak ada perbedaan nyata dilihat dari nilai $\mathrm{P}>0,05$ setelah diuji dengan Man Whitney $U$ test. Oleh karena itu, hipotesis penelitian ke-4 penelitian ini yaitu "ada perbedaan nyata dukungan eksternal dalam pemberdayaan rumah tangga pengolah ikan di pesisir utara (Kabupaten Cirebon) dan pesisir selatan (Kabupaten Sukabumi) Provinsi Jawa Barat" ditolak.

Perbedaan nyata dukungan eksternal di kedua wilayah yaitu pada indikator dukungan bahan baku ikan laut (nilai $P<0,05$ ). Ketersediaan bahan baku ikan laut di pesisir utara (Kabupaten Cirebon) bersifat musiman tapi bisa diperkirakan, bahkan bahan baku pindang cenderung tersedia setiap hari yang dipasok oleh bakul atau perusahaan cold storage. Sebaliknya ketersediaan bahan baku di pesisir selatan (Kab. Sukabumi) bersifat musiman dan sulit diprediksi, bahkan sering terjadi kelangkaan. Oleh sebab itu, harga bahan baku di pesisir utara (Kabupaten Cirebon) lebih murah dibandingkan dengan di pesisir selatan (Kabupaten Sukabumi).

Peran pemerintah dalam memberikan bantuan peralatan, bantuan modal, dan pelayanan administrasi perizinan di pesisir utara (Kabupaten Cirebon) dan pesisir selatan (Kabupaten Sukabumi) tergolong rendah. Tidak ada perbedaan peran pemerintah di kedua wilayah dalam proses pemberdayaan pengolah ikan (nilai $P=0,05$ ).
Bantuan peralatan dan modal usaha di kedua wilayah juga masih rendah. Pengolah ikan di kedua wilayah hanya sedikit atau kurang dari 40 persen yang menerima bantuan peralatan dan menganggapnya telah sesuai kebutuhan, sedangkan pengolah ikan yang menerima bantuan uang tunai dari program PUMP kurang dari 30 persen. Bagi pengolah ikan di kedua wilayah yang menerimanya merasa cukup memadai untuk modal kerja. Bantuan tersebut diterima rata-rata antara 30 juta sampai dengan 50 juta rupiah per kelompok.

Pengolah ikan yang pernah mengurus perizinan di kedua wilayah kurang dari 20 persen. Pengolah ikan di pesisir selatan (Kabupaten Sukabumi) lebih banyak yang mengurus izin daripada di pesisir utara (Kabupaten Cirebon). Para pengolah ikan di kedua wilayah menganggap proses perizinan mudah, cepat, dan murah.

Usaha pengolahan ikan skala rumah tangga sekurang-kurangnya harus memiliki izin pangan industri rumah tangga (PIRT) dan sertifikat halal. PIRT diterbitkan oleh Dinas Kesehatan sedangkan sertifikat halal diterbitkan oleh MUI. Namun, pelaksanaannya PIRT dan Halal pengurusannya dibantu oleh Dinas Perindustrian dan Perdagangan atau Dinas Kelautan dan Perikanan. Selain itu, pengolah ikan harus memiliki surat ijin usaha (SIUP), bahkan perlu juga memiliki surat ijin usaha dari desa seperti pengolah ikan di Kabupaten Cirebon.

Intensitas penyuluhan perikanan di kedua wilayah tidak ada perbedaan dan termasuk kategori rendah (nilai $P>0,05$ ). Jumlah pengolah ikan yang pernah mengikuti sosialisasi penanganan limbah cair, bahaya formalin, dan kelayakan pengolahan (SKP) di kedua wilayah hampir sama. Akan tetapi, pelatihan manajemen usaha, teknologi pengolahan, dan kemasan produk lebih banyak diikuti oleh pengolah ikan di pesisir selatan (Kabupaten Sukabumi), sedangkan kegiatan study tour dan kunjungan penyuluh lebih sering dilakukan di pesisir utara (Kabupaten Cirebon). Pengolah ikan di kedua wilayah merasa materi penyuluhan perikanan telah sesuai dengan kebutuhan dan masalah saat ini. Materi yang disampaikan di kedua wilayah juga mengandung aspek keberlanjutan dan kreativitas.

Materi sosialisasi penanganan limbah dan pelatihan kemasan meskipun hanya sebagian pengolah yang pernah mengikutinya tapi materi ini sangat bermanfaat untuk membentuk perilaku yang ramah lingkungan dan keretivitas usaha. 
Materi penyuluhan harus sesuai dengan kebutuhan dan minat sasaran (Rayuddin, 2010, Arevin 2014), permasalahan yang muncul saat ini (Fatchiya, 2010), memuat aspek keberlanjutan (Sumardjo, 1999), dan meningkatkan kreativitas (Agus, 2009 dan Arevin, 2014).

Materi penyuluhan juga harus mudah dipahami. Oleh karena itu, penyuluhan perikanan harus menggunakan metode yang tepat. Tujuan penyuluhan dan keragaman khalayak sasaran perlu dipertimbangkan dalam menentukan metode penyuluhan. Metode penyuluhan yang sering dilakukan di kedua wilayah yaitu sosialisasi, pelatihan, kunjungan penyuluh, dan study tour. Persepsi pengolah ikan terhadap metode penyuluhan yaitu materi dipahami saat ceramah. Selain itu, pengolah ikan juga berminat untuk meniru model saat dilakukan study tour, dan merasa mudah menerapkan jika diberikan pelatihan.

Metode lainnya yaitu melalui kunjungan penyuluh. Pengolah ikan di kedua wilayah merasakan kunjungan dari penyuluh masih jarang bahkan sebagian yang lain merasakan belum pernah dikunjungi penyuluh. Penyuluh saat ini masih berorientasi mengajar padahal penyuluh juga harus berperan sebagai pendamping (Ife, 1995).

Disamping itu, pemberdayaan pengolah ikan di Jawa Barat dilakukan melalui pendekatan kelompok. Pemerintah menumbuhkembangkan kelompok pengolah dan pemasar hasil perikanan (poklahsar). Peran kelompok diharapkan sebagai wadah berbagi informasi dan kerjasama pemasaran produk. Peran tersebut di kedua wilayah cenderung sedang dengan skor antara 51 persen sampai dengan 75 persen. Tidak ada perbedaan peran kelompok baik berbagi informasi penting maupun kerjasama pemasaran $(P>0,05)$.

Menurut Robbins (1996) bahwa kelompok diharapkan berperan dalam berbagi informasi dalam pengambilan keputusan. Selain itu, kelompok juga diharapkan dapat meningkatkan kerjasama dalam pemasaran produk. Apabila kelompok berperan secara efektif maka posisi tawar anggota kelompok akan meningkat tetapi peran kelompok di kedua wilayah belum efektif bahkan sebagian pengolah ikan belum berkelompok.

Dukungan permodalan usaha sebagian dari lembaga keuangan dan perseorangan. Perbankan, pegadaian, dan usaha simpan pinjam perseorangan menawarkan kredit pinjaman kepada pengolah ikan di kedua wilayah baik pesisir utara
(Kab. Cirebon) maupun pesisir selatan (Kab. Sukabumi). Permodalan saat ini sudah menjadi usaha komersil. Pengolah ikan meminjam uang tidak sekedar untuk modal usaha saja tetapi untuk kebutuhan rumah tangga juga.

Indonesia belum ada wacana membangun sistem kredit pertanian atau pun perikanan yang dikelola pemerintah. Dana untuk usaha kecil di Indonesia disalurkan melalui perbankan dengan sistem konvensional, sedangkan di Amerika Serikat dukungan permodalan tidak hanya diserahkan pada bank komersil, perorangan, atau asuransi tetapi pemerintah membangun sistem kredit pertanian dan sudah dirasakan manfaatnya oleh 30 persen petani (Monke, 2008).

Dukungan permodalan di kedua wilayah termasuk rendah dan tidak ada perbedaan $(P>0,05)$. Sebagian besar pengolah ikan atau lebih dari 50 persen tidak meminjam modal usaha dari pihak lain. Pengolah di pesisir utara (Kabupaten Cirebon) mengandalkan pinjaman dari perseorangan karena dianggap lebih mudah dalam prosesnya meskipun berbunga tinggi, sedangkan di pesisir selatan (Kabupaten Sukabumi) pinjaman modal sebagian besar dari bank karena bunga bank dianggap lebih rendah daripada perseorangan.

Sistem layanan perbankan masih dipersepsikan rumit dalam proses administrasinya. Beberapa bank yang sudah banyak diakses pengolah ikan seperti bank rakyat Indonesia (BRI), bank perkreditan rakyat (BPR), dan bank tabungan pensiun nasional (BTPN). Pegadaian dipersepsikan mudah dan berbunga rendah tetapi sebagian besar pengolah ikan tidak mengetahuinya.

Usaha pengolahan ikan sangat memerlukan dukungan pasar. Oleh karena itu, kepastian pasar paling menentukan dalam usaha pengolahan ikan. Fluktuasi harga yang tinggi dapat menurunkan motivasi petani sayuran di Jawa Barat (Sumardjo 1999). Kepastian pasar juga menjadi variabel penentu dalam adopsi inovasi yang dibawa oleh penyuluh (Lionberger dan Gwin, 1982).

Dukungan pasar termasuk rendah cenderung sedang dan tidak ada perbedaan dalam pemasaran produk $(P>0,05)$. Pengolah ikan di pesisir utara (Kabupaten Cirebon) menjual produk melalui pedagang perantara, langsung ke konsumen, dan keduanya. Sebaliknya di pesisir selatan (Kabupaten Sukabumi) penjualan 
produk cenderung langsung ke konsumen di pasar-pasar terdekat atau toko penjualan sendiri. Dukungan kepastian pasar produk olahan ikan di kedua wilayah dipersepsikan baik karena volume penjualan cenderung meningkat. Namun, harga jual produk di pesisir utara (Kabupaten Cirebon) lebih baik dibandingkan dengan pesisir selatan (Kabupaten Sukabumi).

Akses penjualan produk oleh pengolah ikan di pesisir selatan (Kabupaten Sukabumi) terbatas pada pasar-pasar tradisional terdekat atau toko di pinggir-pinggir jalan dekat dengan tempat pengolahan ikan. Abon ikan biasanya dijual di toko oleh-oleh terdekat bahkan produk dijual hingga ke luar daerah seperti Bogor dan RangkasbitungBanten.

Akses penjualan produk di pesisir utara (Kabupaten Cirebon) lebih luas lagi. Produk olahan asal Cirebon dijual ke luar daerah seperti Majalengka, Brebes, dan Bandung. Wisata budaya dan religi di Kabupaten Cirebon juga berdampak pada meningkatnya permintaan oleh-oleh. Produk olahan juga bisa dijual di warung-warung dan pasar terdekat. Produk rajungan kupas bahkan sudah diekspor ke luar negeri melalui perusahaan eksportir. Produk khas ikan asap dan kerupuk kulit pari dijual di pusat oleh-oleh dan pasar tradisional. Produk kerang kupas dijual hingga ke Jakarta melalui pedagang pengumpul.

Dukungan sarana air bersih dan peralatan pengolahan ikan di kedua wilayah sangat memadai dan tidak ada perbedaan $(P>0,05)$. Air bersih dan peralatan termasuk input produksi penting. Modal fisik harus dipertimbangkan dalam pengembangan masyarakat (Ferguson dan Dickers, 1999). Air bersih harus dikelola dengan baik oleh pemerintah karena keterbatasan air bersih akan mengakibatkan persaingan dan konflik sosial.

Ketersediaan air bersih di pesisir utara (Kabupaten Cirebon) hampir seluruhnya bergantung pada sumber air tanah sedangkan di pesisir selatan (Kabupaten Sukabumi) pengolah ikan sebagian besar masih bergantung air tanah tapi sebagian lainnya sudah bergantung kepada perusahaan air minum. Air bersih di kedua wilayah tergolong berkualitas baik.

Ketersediaan peralatan pengolahan ikan di pesisir utara (Kabupaten Cirebon) cenderung lengkap tapi harganya mahal. Sebaliknya di pesisir selatan (Kabupaten Sukabumi) ketersediaan peralatan kurang lengkap dan harganya mahal.
Selain itu, usaha pengolahan ikan membutuhkan prasarana penunjang yang dibutuhkan setiap hari. Prasarana transportasi dan tempat pelelangan ikan sangat mendukung keberlanjutan usaha pengolahan. Kondisi prasarana transportasi baik jalan raya maupun kendaraan di kedua wilayah termasuk baik. Persepsi pengolah ikan terhadap prasarana tidak berbeda di kedua wilayah penelitian $(P>0,05)$.

Transportasi dari lokasi bahan baku ke tempat pengolahan ikan di pesisir utara (Kabupaten Cirebon) lancar dan ongkosnya murah sedangkan kondisi transportasi di pesisir selatan (Kabupaten Sukabumi) lancar tapi ongkosnya mahal. Selanjutnya transportasi dari tempat pengolahan ikan ke pasar terdekat di pesisir utara (Kabupaten Cirebon) lancar dan murah sedangkan transportasi ke pasar terdekat di pesisir selatan (Kabupaten Sukabumi) cenderung lancar tapi ongkosnya mahal.

Tempat pelelangan ikan di kedua wilayah dipersepsikan oleh pengolah ikan beroperasi setiap hari. Tempat pelelangan ikan yang aktif setiap hari di Kabupaten Cirebon yaitu TPI Gebang dan Mundu sedangkan di Kabupaten Sukabumi aktif setiap hari TPI Cisolok dan Pelabuhan Ratu.

\section{KESIMPULAN DAN IMPLIKASI KEBIJAKAN}

\section{Kesimpulan}

Tingkat keberdayaan rumah tangga pengolah ikan di kedua wilayah tersebut tidak berbeda dan termasuk kategori sedang. Keberdayaan pengolah ikan dilihat dari kelayakan pengolahan, sikap ramah lingkungan, manajerial, posisi tawar, kreativitas usaha, dan besar keuntungan usaha per bulan. Perilaku pengolah ikan yang perlu ditingkatkan yaitu cara memperlakukan limbah cair, menggunakan penutup kepala saat mengolah ikan, menggunakan talenan saat menyiangi ikan, menggunakan tangki penampung air, menggunakan kemasan yang masih layak pakai, dan menggunakan peralatan yang tahan karat. Selain itu, perlu peningkatan kreativitas usaha seperti membuat produk kualitas super, kemasan menarik, dan promosi produk melalui internet.

Tingkat kesejahteraan rumah tangga pengolah ikan di kedua wilayah tersebut juga tidak ada perbedaan yang signifikan, kecuali pada kualitas dinding rumah. Sebesar 20 persen rumah pengolah ikan di pesisir selatan (Kabupaten Sukabumi) terbuat dari kayu dan bambu. Apabila 
diukur dengan kondisi dinding rumah, luas lantai per kapita, tingkat sanitasi, daya listrik rumah, dan kepemilikan barang rumah tangga maka kesejahteraan pengolah ikan skala rumah tangga di Jawa Barat termasuk kategori tinggi.

Tidak ada perbedaan kondisi eksternal yang mendukung keberdayaan rumah tangga pengolah ikan kecuali bahan baku. Bahan baku di pesisir selatan (Kabupaten Sukabumi) sulit diprediksi bahkan sering terjadi kelangkaan. Dukungan eksternal perlu ditingkatkan lagi terutama penyuluhan perikanan, bantuan peralatan atau modal usaha, dan peningkatan peran kelompok pengolah ikan. Demikian pula tidak ada perbedaan karakteristik umur, tingkat pendidikan, pengalaman usaha, jumlah tanggungan rumah tangga, motivasi usaha, dan kekuatan jaringan usaha baik di pesisir utara (Kabupaten Cirebon) dan pesisir selatan (Kabupaten Sukabumi) Provinsi Jawa Barat.

\section{Implikasi Kebijakan}

Pemberdayaan yang dilakukan oleh pemerintah melalui program nasional pemberdayaan masyarakat mandiri kelautan dan perikanan (PNPM-KP) denga paket PUMP sudah tepat karena dilaksanakan dengan cara memfasilitasi bimbingan usaha, meningkatkan peran kelompok, dan mengedepankan kesetaraan gender. Namun, peran pendamping atau penyuluhan perikanan tidak hanya membantu proses administrasi keuangan program tetapi perlu diarahkan pada upaya peningkatan mutu, kelestarian lingkungan, dan kreativitas usaha.

Kebijakan pemerintah dalam memfasilitasi kebutuhan usaha melalui bantuan peralatan dan modal usaha melalui program PUMP atau program lainnya perlu ditingkatkan lagi baik jumlah penerima maupun kesesuaian bantuan. Selain itu, intensitas penyuluhan di kedua wilayah juga masih rendah sehingga perlu ditingkatkan lagi baik jumlah peserta maupun kesesuaian metode, materi, dan kunjungan penyuluh ke tempat pengolahan ikan. Metode dan materi penyuluhan perikanan sebaiknya fokus pada peningkatan kreativitas usaha, kelayakan pengolahan, dan pengolahan ramah lingkungan.

Peran kelompok dalam berbagi informasi dan kerjasama pemasaran juga masih rendah bahkan masih banyak pengolah ikan yang belum berkelompok. Keberadaan kelompok belum dirasakan manfaatnya, kelompok dibentuk hanya untuk menerima bantuan pemerintah saja. Oleh karena itu, upaya pendampingan kelompok oleh penyuluh perikanan masih sangat diperlukan terutama untuk meningkatkan kerjasama pemasaran produk.

\section{UCAPAN TERIMA KASIH}

Kami mengucapkan terima kasih kepada Badan Riset dan Sumber Daya Manusia, Kementerian Kelautan dan Perikanan (KKP) yang telah memberikan dukungan waktu dan biaya untuk menyelesaikan penelitian tentang pemberdayaan. Penelitian ini, merupakan bagian dari disertasi saya yang berjudul "Pemberdayaan Pengolah Ikan Skala Rumah Tangga di Provinsi Jawa Barat" Terima kasih penulis ucapkan kepada Prof. Dr. Ir. Aida Vitayala S. Hubeis, Dr. Basita G. Sugihen, MA, Dr. Anna Fatchiya, MSi, Prof. Dr. (Ris) Djoko Susanto, Dr. Ir. Luky Adrianto, MSc, dan Prof. (Ris). Dr. Sonny Koeshendrajana, MS. yang telah memberikan masukan dalam penelitian ini

\section{DAFTAR PUSTAKA}

Agus, N. F. 2009. Keberdayaan dan Strategi Pelaksanaan Penyuluhan Masyarakat Nelayan Kota Bengkulu. Disertasi. Institut Pertanian Bogor. Program Doktor IImu Penyuluhan Pembangunan. Bogor.

Arevin, A. T. 2014. Pemberdayaan Pemilik Usaha Pondok Wisata Pesisir Di Lima Kawasan Strategis Pariwisata Nasional. Disertasi. Institut Pertanian Bogor. Program Doktor IImu Penyuluhan Pembangunan. Bogor.

Bandura, A. 1977. Social Learning Theory. Prentice-Hall Inc Pr. New Jersey.

Borbye, L. 2010. Out of The Comfort Zone:New Way To Teach, Learn, and Assess Essential Professional Skill. Morgan \& Claypool. North Carolina.

Fatchiya, A. 2010. Pola pengembangan kapasitas pembudidaya ikan air tawar di Provinsi Jawa Barat [disertasi]. Bogor (ID): Institut Pertanian Bogor.

Ferguson, R. F. dan W. T. Dickers. 1999. Urban Problems and Community Development. Brooking Institution. Washington.

Fukuyama, F. 1995. Trust: The Social Virtues And The Creation Of Prosperity. Free. New York.

Granovetter, M. 1973. The Strength Of Weak Ties. American Journal of Sociology. Vol 78 (6):1360-1380.

Halpern, D. 2005. Social Capital. The Policy. Cambridge. 
Havighurst, R.J. 1972. Developmental Task and Education 3rd Edition. McKay Company. New York.

Ife, J. 1995. Community Development: Creating Community Alternatives, Vision, Analysis and Practice. Longman. Australia. Karnaen, S.M.N. dan S. Amanah. 2013. Peranan Gender Dalam Rumah Tangga Perikanan Di Desa Tanjung Pasir, Kecamatan Teluknaga, Kabupaten Tangerang. Sodality. Vol 1(2): 152 - 164

Lionberger, H.F. dan P. H. Gwin. 1982. Communication Strategies: A Guide for Agricultural Change Agents. The Interstate Printers Publisher. Illinois.

Lippitt, R. 1953. Planned Change: A Comparative Study Of Principles And Techniques. Harcourt, Brace, and World Inc. New York.

Maslow, A.H. 1954. Motivation and Personality. Harper \& Row. New York.

Maslow, A. H. and R. Frager. 1987. Motivation and Personality (Rev ed). Harper \& Row. New York.

Milen, A. 2001. What Do We Know Capacity Building:An Overview Of Existing Knowledge And Good Practice. http://apps.who.int/iris/ bitstream/10665/67394/1/a76996.pdf (diakses 29 April 2017).

Monke, J. 2008. Agricultural Credit: Institutions And Issues. Bishoff, J.M, editor. Nova Science Publisher. New York.

Muflikhati, I., Hartoyo, U. Sumarwan, A. Fachrudin dan H. Puspitawati. 2010. Kondisi Sosial Ekonomi Dan Tingkat Kesejahteraan Keluarga: Kasus Di Wiayah Pesisir Jawa Barat. Jurnal IImiah Keluarga dan Konsumen. Vol 3(1): 1 - 10.

Rayuddin. 2010. Pengembangan Kompetensi Agribisnis Petani Kakao Di Kabupaten Konawe Provinsi Sulawesi Tenggara. Disertasi. Institut Pertanian Bogor. Program Doktor IImu Penyuluhan Pembangunan. Bogor.
Robbins, S. P. 1996. Perilaku Organisasi. Prenhallindo. Jakarta.

Rubzen, M.F.R. and J. Burgess. 2016. Human Development And Capacity Building Asia Pacific Trends, Challenges and Prospects For The Future. Routledge. New York.

Rusli, S. 1995. Pengantar Kependudukan. Universitas Indonesia. Jakarta.

Sadono, D. 2012. Model Pemberdayaan Petani Dalam Pengelolaan Usahatani Padi Di Kabupaten Karawang Dan Cianjur, Provinsi Jawa Barat. Disertasi. Institut Pertanian Bogor. Program Doktor IImu Penyuluhan Pembangunan. Bogor.

Soepratikno, S. S. 2015. Model Pemberdayaan Nelayan Berbasis Penggunaan Media Komunikasi Di Pulau Pasaran Kota Bandar Lampung. Disertasi. Institut Pertanian Bogor. Program Doktor IImu Penyuluhan Pembangunan. Bogor.

Sumardjo. 1999. Transformasi Model Penyuluhan Pertanian Menuju Pengembangan Kemandirian Petani, Kasus Di Provinsi Jawa Barat. Disertasi. Institut Pertanian Bogor. Program Doktor IImu Penyuluhan Pembangunan. Bogor.

Tomer, J.F. 2001. Economic Man Vs Heterodox Men: The Concept Of Human Nature In Schools Of Economic Thought. The Journal of SocioEconomics. Vol 1 (30): 281 - 293.

Tracy, B. 2012. The Power of Self-Confidence: Become Unstoppable, Irresistible, and Unafraid In Every Area Of Your Life. John Wiley \& Sons. New Jersey. 